Assiut University web-site: www.aun.edu.eg

\title{
EPIDEMIOLOGICAL STUDY ON BOVINE EPHEMERAL FEVER VIRUS (BEFV) INFECTION IN CATTLE AND BUFFALOES IN EGYPT
}

\author{
TAHA A.A. EL-ALLAWY; FATMA S. MAHMOUD AND SAFAA S. MALEK \\ Department of Animal Medicine, Faculty of Veterinary Medicine, Assiut University
}

Received: 3 October 2021; Accepted: 30 October 2021

\begin{abstract}
The present study was conducted on 156 cattle and buffaloes. The age of these animals between 6 months to 4years, they examined during the period from January 2018 to September 2019. These animals from different localities in Assiut, sohag and El-Menia governorates. The investigated animals characterized by sudden onset of fever in $25.64 \%$ (40 /156) ranged from $40^{\circ}$ to $42^{\circ} \mathrm{C}$ associated with severe congested mucous membranes, dry muzzle, foamy salivation, dullness, sickness, shivering and trembling, rapid shallow respiration in $19.23 \%(30 / 156)$ and ruminal stasis in $25 \%(39 / 156)$, enlargement of superficial lymph nodes. $7.05 \%(11 / 156)$ and $6.41 \%(10 / 156)$ of the examined cases showed drop in milk production and abortion, respectively. Little number of cases showed recumbency, subcutaneous emphysema and lameness respectively $1.28 \%(2 / 156), 0.64 \%(1 / 156)$ and $3.21 \%(5 / 156)$. The serological detection for ephemeral fever virus antigen was $9.52 \%(8 / 84)$, and $4.76 \%(2 / 42)$ were positive for virus antibodies. $40 / 50(80 \%)$ were positive for RTPCR. The prevalence of infection was 17.95\% (28/156) in Assiut governorate, 5.77\% (9/ 156) in Sohag, 1.92\% (3/ 156) in El-Menia. Frezian breeds had higher rate of infection $13.46 \%$ $(21 / 156)$ than native breeds $6.41 \%$ (10/156) followed by buffaloes was $5.77 \%(9 / 156)$. The infection in females was $17.31 \%$ (27/ 156) but in males was $8.33 \%$ (13/156). The age group $>2-4$ years $(13.45 \%)$ was more susceptible to virus infection than age group 6 months-2 years $(12.5 \%)$. The infection rate was higher in hot months $19.23 \%(30 / 156)$ than non- hot months $6.41 \%(10 / 156)$.
\end{abstract}

Key words: BEFV infection, Assiut Governorate, Epidemiology

\section{INTRODUCTION}

Bovine ephemeral fever (BEF) is a non-contagious viral disease of cattle and water buffaloes (Zaghawa et al., 2017; Lee, 2019 and Huihuiet al., 2020). It is a vector born acute febrile disease in tropical and

Corresponding author: Safaa S. Malek

E-mail address: safaamalek80@aun.edu.eg

Present address: Department of Animal Medicine, Faculty of Veterinary Medicine, Assiut University subtropical regions of Africa, Asia, Australia and the Middle East (Aziz-Boaron et al., 2012; Kun et al., 2020). BEF is characterized by high morbidity rates may be up to $100 \%$, however the mortality rate is generally low (rarely exceeds $1 \%$ ), but cattle in good condition are usually affected more severely and the mortality rate can be as high as $30 \%$ in very fat cattle and in outbreaks of bovine ephemeral fever the morbidity rate may be as high as $80 \%$ (Momtaz et al., 2012 and Zaghawa et al., 2017). BEF is considered one of the diseases 
which have economic impact as loss of milk production in quality and quantity, loss of condition in beef herds, infertility and abortion (Bakhshesh and Abdollahi, 2015 and Jiang et al., 2019). The disease is characterized clinically by a sudden onset of fever as high as $41^{\circ} \mathrm{C}$, sudden and sever drop in milk production, in appetence, lethargy, salivation, nasal discharge and depression (Tonbank et al., 2012 and Pasandideh et al., 2019). Diagnosis of BEF begins with the history of the outbreak and clinical exanimation of the affected animals. Serological tests as blocking Enzyme linked immunosorbent assay (ELISA) and reverse transcriptase polymerase chain reaction (RTPCR) are the more accurate methods used for diagnosis of the disease (Zaher and Ahmed, 2011; Kasem et al., 2014 and Alkan et al., 2017). Because of lack of information about this virus in Assiut governorate, the aim of our study is to determine the virus prevalence by using ELISA test and RTPCR test.

\section{MATERIALS AND METHODS}

\section{Animals:}

During the period of investigation from January 2018 to September 2019, a total number of 156 cattle and buffaloes (72 Frezian, 33 native breed cattle and 51 buffaloes) of different ages (6 months to 4 years divided into different groups) and sexes, were clinically examined, serologically and molecularly tested for the presence of BEFV. These animals were admitted to Veterinary teaching hospital in Faculty of Veterinary medicine, Assiut University from different localities in Assiut Governorate, the farm of El- Dyabat in Sohag and El-Menia governorate. Depending on history taking, the clinically examined animals were not vaccinated against BEFV. These animals examined clinically according to (Rosenberger, 1979 and Radiostits et al., 2007) any deviation from normal was recorded.

\section{Samples:}

Whole blood and serum samples were collected from jugular vein of 156 cattle and buffaloes in vacutainer tubes with or without anticoagulant on which the date, number, age and sex of the animal in addition to the address of the owner were registered. The whole blood samples were preserved at $-80^{\circ}$ $C$ deep freeze until used for molecular examination. The serum samples were collected by taking blood samples in vacutainer tube without anticoagulant, then preserved in refrigerator for 1 hour, and centrifuged at 3000 r.p.m for 15 minutes. Serum samples were preserved at $-20^{\circ} \mathrm{C}$ deep freeze until used for serological examination (ELISA antibody and antigen).

\section{Serological Diagnosis:}

- Bovine ephemeral fever virus antigen (BEFV- Ag) ELISA kit: (Sino Gene Clone Biotech Co., Ltd), (Catalog No.: SG- 60602).

- Bovine ephemeral fever virus antibody (BEFV- Ab) ELISA kit: (Sino Gene Clone Biotech Co., Ltd), (Catalog No.: SG- 60601)

\section{Molecular diagnosis:}

- Kits for RNA extraction according to (Momtaz et al., 2012) was Qiagen ${ }^{\circledR}$ QIAamp Viral RNA Mini Kit, (QIAGEN, GmbH, Germany). LOT (151034653), CAT. No. 5290, No. of Preps 50.

\section{- Primers:}

The presence of BEFV was confirmed by RT- PCR as described by (Kasem et al., 2014) by using the sequences of the primers as follows:

380Forward (F) (5' AGA GCT TGG TGT GAA TAC 3')

380Reverse (R) (5' CCA ACC TAC AAC AGC AGA TA 3') (Zheng and Qui, 2012).

- Master Mix: Qiagen ${ }^{\circledR}$ OneStep RTPCR Kit (Qiagen, Hilden, Germany).

\section{- Identification of PCR products}


After amplification, $1.5 \%$ agarose was prepared for the step of Gel electrophoresis and the bands of PCR products at $380 \mathrm{bp}$

\section{Statistical analysis}

- All data were analyzed by Chi-square of independence formula that used by Statistical package for the social sciences (SPSS) version 16 software program (2007).

\section{RESULTS}

During the period of investigation from January 2018 to September 2019, one hundred and fifty-six (156) cattle and buffaloes were inspected and clinically, serologically and molecularly examined for BEFV infection.

\section{Results of clinical examination:}

The clinical signs of BEF infection noticed were sudden onset of fever in $25.64 \%$ of cases (40 out of 156$)$ ranged from $\left(40^{\circ}\right.$ to $42^{\circ} \mathrm{C}$ ) associated with severe congested mucous membranes as in photo (1), dry muzzle, foamy salivation as in photo (2), dullness, sickness, shivering and trembling, $19.23 \%$ (30/156) from the examined cases showed rapid shallow respiration and $25 \%$ $(39 / 156)$ of the investigated animals suffered from rumenal stasis. Most of the observed animals showed enlargement of superficial lymph nodes as in photo (3). As a result of fever, $7.05 \%(11 / 156)$ and $6.41 \%(10 / 156)$ of the examined cases showed drop in milk production and abortion, respectively. Little number of cases showed recumbency as, subcutaneous emphysema and lameness respectively $1.28 \%(2 / 156), 0.64 \%(1 / 156)$ and $3.21 \%(5 / 156)$.

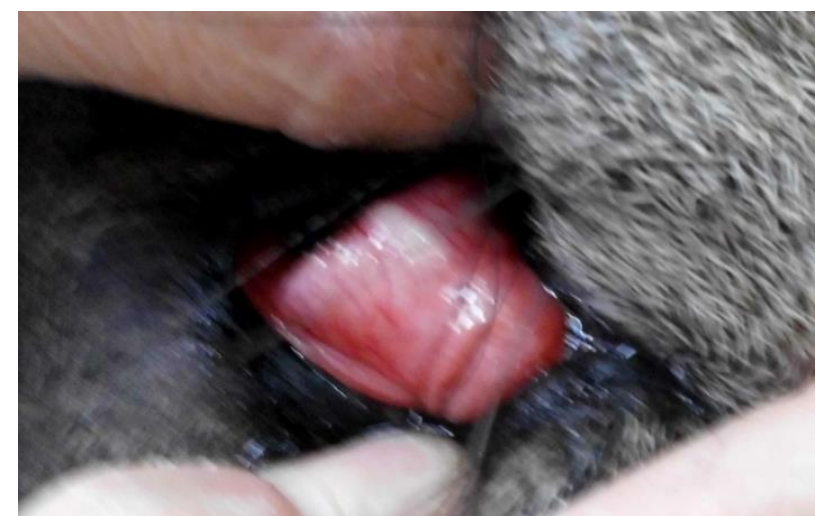

Photo (1): Congested mucus membrane of the eye (Fever)

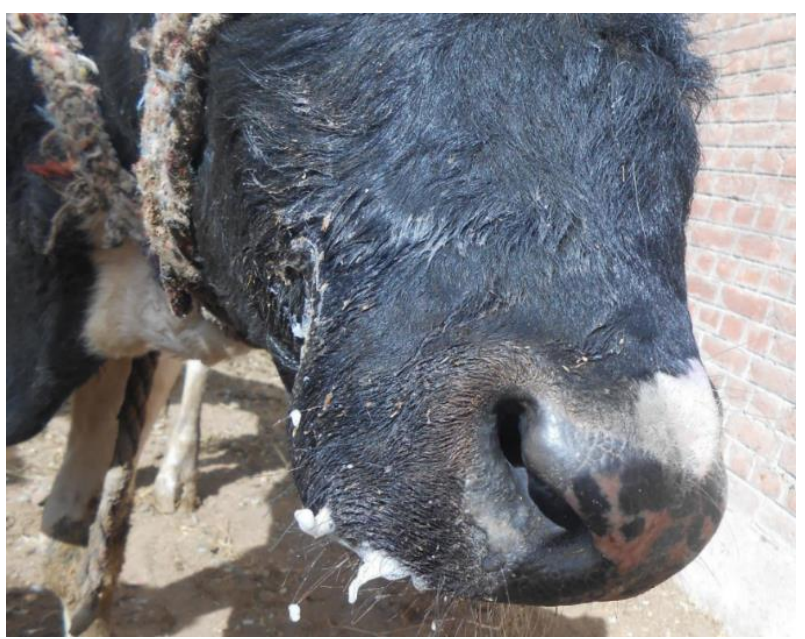

Photo (2): Dry muzzle (fever) 


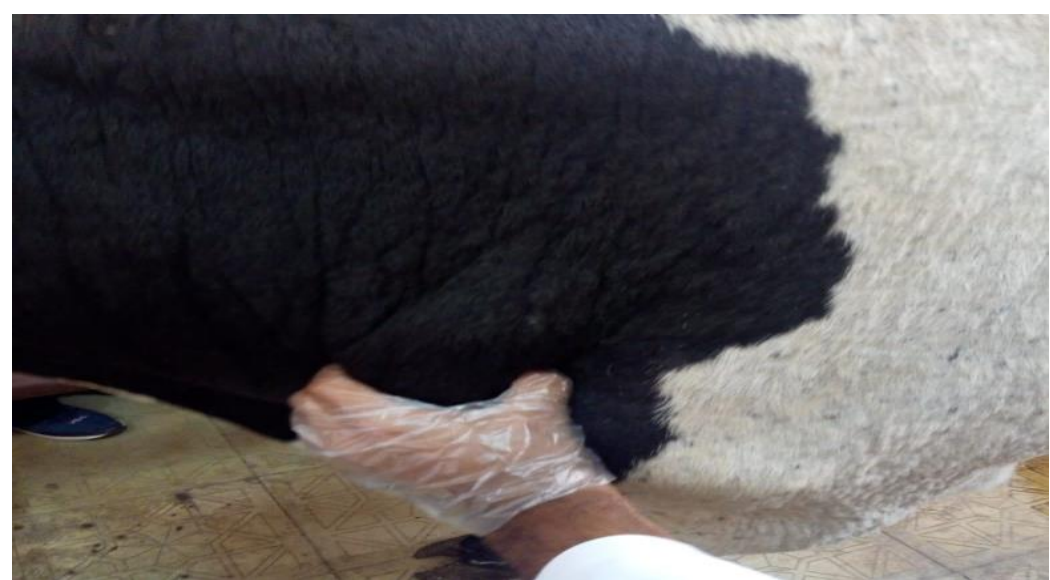

Photo (3): Enlargement of prescapular lymph node.

Table 1: Results of clinical examination:

\begin{tabular}{ccc}
\hline Clinical finding & No. of +ve cases & \% \\
\hline $\begin{array}{c}\text { Fever (congested mucus membranes, dry muzzle, foamy } \\
\text { salivation, dullness, sickness, shivering and trembling) }\end{array}$ & $40 / 156$ & 25.64 \\
\hline Respiratory signs (cough and shallow, rapid respiration) & $30 / 156$ & 19.23 \\
\hline Rumenal stasis & $39 / 156$ & 25 \\
\hline Enlarged superficial lymph nodes & $35 / 156$ & 22.44 \\
\hline Drop in milk production & $11 / 156$ & 7.05 \\
\hline Abortion & $10 / 156$ & 6.41 \\
\hline Recumbency & $2 / 156$ & 1.28 \\
\hline Subcutaneous emphysema & $1 / 156$ & 0.64 \\
\hline Lameness & $5 / 156$ & 3.21 \\
\hline
\end{tabular}

\section{Results of serological diagnosis:}

ELISA test used for detection of BEFV Antigen revealed that $9.52 \%$ (8 out of 84 ) of serum samples were positive, while ELISA test used for detection of BEFV Antibodies revealed that $4.76 \%$ ( 2 out of 42 ) of serum samples were positive as in Table (2).

Table 2: Prevalence of BEFV infection in the examined animals by ELISA test.

\begin{tabular}{cccc}
\hline ELISA test & $\begin{array}{c}\text { Number of the } \\
\text { examined cases }\end{array}$ & $\begin{array}{c}\text { Number of } \\
\text { positive cases }\end{array}$ & percentage \\
\hline $\mathrm{Ag}$ & 84 & 8 & 9.52 \\
\hline $\mathrm{Ab}$ & 42 & 2 & 4.76 \\
\hline
\end{tabular}

\section{Results of molecular diagnosis:}

40 out of $50(80 \%)$ examined samples showed the specific band at $380 \mathrm{bp}$ after
PCR amplification of $\mathrm{G}$ gene of BEFV by using RT- PCR as shown in Photo (4) and Table (3). 


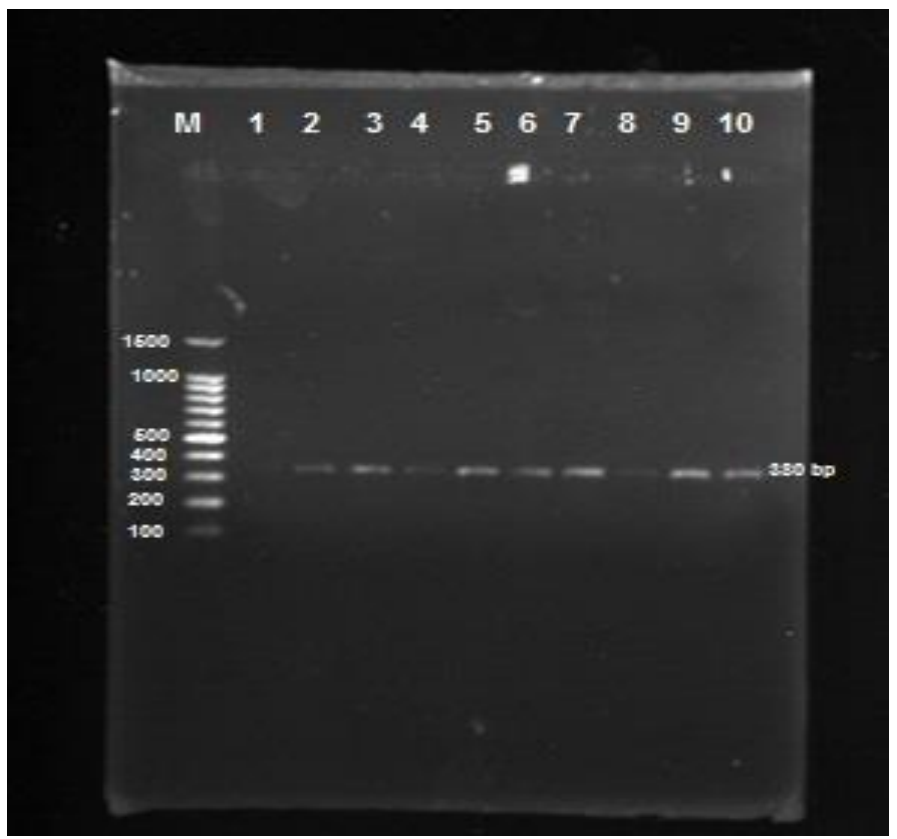

Photo (4): Agarose gel electrophoresis of RT-PCR amplification of G gene of BEFV Lane M: DNA Marker of 100bp.

Lanes 2, 3, 4, 5, 6, 7, 8, $9 \& 10$ : Positive samples with amplified product at $380 \mathrm{bp}$.

Table 3: The positive results of RT-PCR

\begin{tabular}{ccc}
\hline Examined samples & \multicolumn{2}{c}{ RT-PCR } \\
\hline \multirow{2}{*}{50} & No. & $\%$ \\
\cline { 2 - 3 } & 40 & 80 \\
\hline
\end{tabular}

Comparison between ELISA and RTPCR in diagnosis of BEFV:

The positive BEFV examined animals by ELISA and RT-PCR was higher significant than investigated animal by ELISA only or RT-PCR only. Total numbers of examined cases in our study were 156 animals, 106 cases out of 156 animals were tested by ELISA only and 10 cases from them were positive for BEFV infection. 50 out of 156 cases were tested by PCR only and 40cases were positive for BEFV infection as shown in table (4).

Table 4: Prevalence of BEFV infection in the examined cases by ELSA and RT-PCR

\begin{tabular}{ccccccc}
\hline $\begin{array}{c}\text { Total number of examined } \\
\text { animals }\end{array}$ & \multicolumn{3}{c}{ ELISA } & \multicolumn{4}{c}{ RT-PCR } \\
\hline \multirow{2}{*}{156} & No. & Positive & $\%$ & No. & Positive & $\%$ \\
\cline { 2 - 7 } & 106 & 10 & 9.43 & 50 & $40 * * *$ & $\mathbf{8 0 \%}$ \\
\hline
\end{tabular}

$* * *$ Highly significant increase at $\mathrm{p}<0.001$ 
Table 5: Difference between serological and molecular techniques for diagnosis of BEFV The 20 cases in this table were out of 156 animals (the total number of the examined cases) were tested by both ELISA and PCR and 4 cases from them were positive by ELISA and the other 16 cases were positive by PCR.

\begin{tabular}{ccccc}
\hline Examined cases & \multicolumn{2}{c}{$\begin{array}{c}\text { Serological test } \\
\text { (ELISA) }\end{array}$} & \multicolumn{2}{c}{ Molecular technique RT-PCR } \\
\hline \multirow{2}{*}{20} & No. & $\%$ & No. & $\%$ \\
\cline { 2 - 5 } & 4 & 20 & 16 & $80^{* * *}$ \\
\hline
\end{tabular}

***Highly significant increase at $\mathrm{p}<0.001$.

Table (6): Results of moleculer examination:

These 20 cases out of 156 animals were examined by both ELISA and PCR and resulted those 4 cases being positive for both ELISA and PCR, 13 cases were positive for PCR and negative for ELISA and 3 cases were negative for both PCR and ELISA.

\begin{tabular}{ccccccc}
\hline $\begin{array}{c}\text { Total No. of the } \\
\text { examined cases }\end{array}$ & \multicolumn{2}{c}{$\begin{array}{c}\text { +ve RT-PCR } \\
\text { and +ve ELISA }\end{array}$} & $\begin{array}{c}\text { +ve RT-PCR and } \\
\text {-ve ELISA }\end{array}$ & \multicolumn{2}{c}{$\begin{array}{c}\text {-ve PCR and -ve } \\
\text { ELISA }\end{array}$} \\
\hline \multirow{2}{*}{20} & No. & $\%$ & No. & $\%$ & No. & $\%$ \\
\cline { 2 - 7 } & 4 & 20 & 13 & $65^{* * *}$ & 3 & 15 \\
\hline
\end{tabular}

***Highly significant increase at $\mathrm{p}<0.001$.

\section{Epidemiological findings:}

\section{A-Prevalence of BEFV infection:}

Prevalence of BEFV infection in the examined cases was $25.64 \%$ (40/156). The prevalence of BEFV infection in different localities in Upper Egypt indicated that
Assiut had the highest rate of infection $17.95 \%$ (28/156). The prevalence of BEFV infection in Sohag and El- Menia were $5.77 \%(9 / 156)$ and $1.92 \% \quad(3 / 156)$, respectively as observed in Table (7).

Table 7: Percentage of infection with BEFV in different governorates in Upper Egypt.

\begin{tabular}{cccc}
\hline \multirow{2}{*}{ Locality } & \multirow{2}{*}{ Examined cases } & \multicolumn{2}{c}{ Positive cases } \\
\cline { 3 - 4 } & & No. & \% \\
\hline Assiut & 80 & 28 & $17.95^{* * *}$ \\
\hline Sohag & 36 & 9 & 5.77 \\
\hline El-Menia & 40 & 3 & 1.92 \\
\hline Total & 156 & 40 & 25.64 \\
\hline
\end{tabular}

B- Breed susceptibility:

The relationship between BEFV infection and breed susceptibility revealed that frezian breeds had higher rate of infection $13.46 \%$
(21/156) than native breeds $6.41 \%(10 / 156)$ followed by buffaloes was $5.77 \%(9 / 156)$ as observed in Table 8.

Table 8: Prevalence of BEFV infection in different breeds of cattle and buffaloes.

\begin{tabular}{cccc}
\hline \multirow{2}{*}{ Breed } & \multirow{2}{*}{ Examined cases } & \multicolumn{2}{c}{ Positive cases } \\
\cline { 3 - 4 } & & No. & \% \\
\hline Frezian & 72 & 21 & 13.46 \\
\hline Native & 33 & 10 & 6.41 \\
\hline Buffaloes & 51 & 9 & 5.77 \\
\hline Total & 156 & 40 & 25.64 \\
\hline
\end{tabular}

Non-significant difference at $\mathrm{p}<0.05$. 


\section{C-Sex susceptibility:}

Female animals had higher infection rate infection in females was $17.31 \%$ (27 out of than males to BEFV. The prevalence of 156 ) but in males was $8.33 \%$ (13 out of 156 ) as shown in Table 9.

Table 9: Prevalence of BEFV infection in both sexes of cattle and buffaloes.

\begin{tabular}{cccc}
\hline \multirow{2}{*}{ Sex } & \multirow{2}{*}{ Examined cases } & \multicolumn{2}{c}{ Positive cases } \\
\cline { 3 - 4 } & & No. & \% \\
\hline Male & 58 & 13 & 8.33 \\
\hline Female & 98 & 27 & 17.31 \\
\hline Total & 156 & 40 & 25.64 \\
\hline
\end{tabular}

Non- significant at $\mathrm{p}<0.05$.

\section{D-Age susceptibility:}

In our study, the observed animals ranged from 6 months to 4 years. In the age group

(>2 to 4 years) had higher infection rate $13.45 \%(21 / 156)$ than age group (6 months to 2 years) $12.18 \%(19 / 156)$ as in Table 10.

Table 10: Prevalence of BEFV infection in cattle and buffaloes at different age groups.

\begin{tabular}{cccc}
\hline \multirow{2}{*}{ Age } & \multirow{2}{*}{ Examined cases } & \multicolumn{2}{c}{ Positive cases } \\
\cline { 3 - 4 } & & No. & \% \\
\hline 6 months-2 years & 40 & 19 & 12.18 \\
\hline >2-4 years & 116 & 21 & $13.45^{* * *}$ \\
\hline total & 156 & 40 & 25.64 \\
\hline
\end{tabular}

$* * *$ Highly significant increase at $\mathrm{p}<0.001$.

\section{E-Seasonal variation:}

In the present study, the prevalence of BEFV in hot months 32.61\% (30/156) than noninfection in the examined cases was higher hot months $15.62 \%(10 / 156)$ as in Table 11.

Table 11: Influence of seasonal variation on the prevalence of BEFV infection.

\begin{tabular}{cccc}
\hline \multirow{2}{*}{ Months } & \multirow{2}{*}{ Examined cases } & \multicolumn{2}{c}{ Positive cases } \\
\cline { 3 - 4 } & 92 & 30 & $19.23^{*}$ \\
\hline Hot months & 64 & 10 & 6.41 \\
\hline Non-hot months & 156 & 40 & 25.64 \\
\hline Total & & &
\end{tabular}

* Significant difference at $\mathrm{p}<0.05$.

\section{DISCUSSION}

BEF is an arthropod- borne disease of cattle and water buffaloes. BEFV infection occurs seasonally in tropical, subtropical and high temperate regions of Africa, Asia and Australia, BEF is considered as a member of the genus Ephemerovirus in the family Rhabdoviridae, the characteristic clinical signs of BEF are sudden onset of a high fever, anorexia, depression, ocular and nasal discharges, salivation, muscle stiffness, lameness, rumenal stasis, sternal recumbency and other inflammatory responses. The disease can cause economic impact through the sudden drop of milk production in dairy cattle and loss of condition in beef cattle, these detected results agreed with (Zaher and Ahmed, 2011; Bakhshesh and Abdollahi, 2015; 
Hayama et al., 2016; Mirazaie et al., 2017; Lapira et al., 2018 and Lee, 2019).

The investigated animals showed a very high temperature ranged from $\left(40\right.$ to $\left.42^{\circ} \mathrm{C}\right)$ or more, severe congested mucous membranes, rapid and shallow respiration, body shivering and muscle trembling. The examined cases showed dullness, sickness, foamy salivation, sudden drop in milk production, enlargement of superficial lymph nodes, cessation of rumination, some cases had constipation, and some had diarrhea. A small number from the examined cases showed lameness and recumbency, the pregnant cows aborted during the stage of fever. A very small number of cases showed subcutaneous emphysema at the region of the hind quarters and in the gluteal muscles and recumbency, these results were in agreement with (El-Nesr et al., 2010 and Zaher and Ahmed, 2011). The clinical signs related to BEFV infection which detected in our study mainly may be attributed to increasing the vascular permeability and release of cytokines and Interleukins (IL-2 and IL-6) and inflammatory biomarkers as (cortisone, CRP) and decrease in calcium concentration that resulted from the inflammatory response associated with the disease, pulmonary and subcutaneous emphysema may be indicated to the nutritional Selenium deficiency and replication of BEFV in the reticuloendothelial tissues as lung, spleen and lymph nodes. The short incubation period, sudden onset and sudden recovery of BEF may be interpreted by the key role of the released neutralizing antibodies in protection against the disease and these interpretations were in agreement with (ElNesr et al., 2010; Al-Behwar et al., 2018 and Abo-Sakaya and Bazan, 2020).

The prevalence of BEF infection in the current study revealed that disease could be affected by several factors including age, locality and seasonal variation. Our study revealed that the infection rate of BEFV infection in our examined cases was 25.64\% (40/156) in Assiut governorate, these results were nearly similar to (Momtaz et al., 2012) who detected 29\% of the examined cases were positive for BEFV infection in Iran, (Bakhshesh and Abdullahi, 2015) in Iran that detected 27\% of cases were positive in Turkey, (Degheidy et al., 2011) also detected $23.1 \%$ of the examined cases were positive in el-Giza, Egypt; in addition to (Alkan et al., 2017) who detected $25 \%$ of cases were positive for BEFV infection in Turkey-Ankara for BEFV G gene, although (Zaghawa et al., 2017) detected $25 \%$ of the examined cases were positive in Saudia Arabia and (Al-Sultany and Hassan, 2013) who reported $24.44 \%$ from the examined cases were positive for BEFV infection in Iraq. The higher intensity of infection in cattle and buffaloes may be attributed to the bad hygienic condition which helps on the spreading of vector (Culicoides midges and mosquitoes) of the disease, in addition to the climatic condition that occurs in summer season, as due to lack of rains in summer season together with presence of stagnant water may create a favorable habitat for the vector reproduction leading to BEFV expansion.

In the present study, the serological technique used for detection of BEFV infection was blocking ELISA-Ag and ELISA-Ab. Using of ELISA for detection of antigen of BEFV revealed that $9.30 \%$ (8 out of 86) of serum samples were positive, these results were lower than that recorded by (Zheng et al., 2010) who detected that ELISA test had $100 \%$ sensitivity and 96.7\% specificity and gave 336 positive samples in Japan. Although our detected results were nearly similar to that detected by (Momtaz et al., 2011) in Iran, the 
variation between our results and those of other studies may be attributed to geographical variation and differences in timing of samples collection and also may be due to the small number of the collected samples in addition to the high proportion of non- immunized cattle in the examined serum samples and this allowed the BEFV to be transmitted and caused the disease among cattle herds and this in agreement with (Li et al., 2015).

Currently, RT-PCR was more efficient and reliable than the used serological method (Blocking ELISA $\mathrm{Ag}$ and $\mathrm{Ab}$ ) for detection of BEFV infection in cattle and buffaloes (RT-PCR 80\% (40/50) - ELISAAg $9.30 \%$ (8 out of 86$)$ ), the serological technique was lower than that recorded by the molecular techniques (RT-PCR) and these results were similar to previously recorded by (Kasem et al., 2014; Alkan et al., 2017; Zaghawa et al., 2017 and Lapira et al., 2018) who observed that RT-PCR was the most sensitive test used for diagnosis of BEF compared to other tests especially ELISA because RT-PCR has many advantages such as possibility to detect as little as 2 fragments of viral RNA and confirmation of diagnosis of BEFV, sensitive, specific and rapid diagnosis of the disease in Egypt, moreover we found that RT-PCR assay was useful for testing RNA samples extracted from whole blood.

Our results were also in agreement with (Bakhshesh and Abdollahi, 2015) who found that an accurate and reliable diagnosis by using molecular approach for detection of widely spread of viral agent and the application of RT-PCR in the future will definitely increase the sensitivity of BEFV diagnosis and will help to reveal the real extent of virus, our results were in agreement with (Tonbank et al., 2012) who detected $80 \%$ of cases were positive for BEFV infection by RTPCR in Turkey, but in contrast with
(Degheidy et al., 2011) in which his results were less than our results who detected $45.4 \%$ positive cases by RT-PCR and this may be contributed to there was no vaccination program against $\mathrm{BEFV}$ in Egypt.

Additionally, our observations in the current study were in agreement with (Zheng et al., 2010 and Mirazaie et al., 2017) who revealed that rapid spread of BEF epidemics from the primary foci was most probably supported by dense populations of susceptible cattle, breeding places of vectors, climatic and ecological conditions that susceptible for propagation and dispersal of massive numbers of vectors and so contributed considerably to the fast spread of the disease, in addition to virus strain and high sensitivity of cattle population, low level of awareness among practioners, owners, and farm managers about the disease, inappropriate management of collecting manure and communication between farm workers were identified as a risk factors for disease occurrence. The results reported by (Tamam and Abdel-Moneim, 2005) in Egypt were in agreement with our study and this may be due to the majority of domestic animalspopulations were not subjected to vaccination for BEFV, although high prevalence rate may be due to the ability of the virus to reactivate from latency that it is responsible for recurrence of the disease and increased rate of virus transmission.

According to Locality in the current study, there was a relationship between the rate of BEFV infection and localities, in which the percentage of infection in Assiut 17.95\% was higher than in Sohag and El-Menia, $5.77 \%$ and $1.92 \%$, respectively, this may be attributed to number of collected samples in Assiut governorate were more than those collected from Sohag and ElMenia governorates because most of our 
samples were collected from the incoming cases to the Veterinary teaching hospital, Faculty of Veterinary medicine, Assiut governorate and the high percentage of infection in Assiut may be due to lack of immunization and the owners didn't use the vaccination program against BEF.

In relation to the breed of the animals in our study, the infection rate of BEFV was $13.46 \%$ in Frisian breeds of cattle and $6.41 \%$ in native breeds of cattle and $5.77 \%$ in buffaloes, in which, the infection rate in Frisian breeds of cattle was higher than in native breeds of cattle and buffaloes that similar to the results showed previously by (Momtaz et al., 2012 in Iran; Zaher and Ahmed, 2012 in Egypt; Niwa et al., 2015 in Japan and Zaghawa et al., 2017 in Saudia Arabia) and this may be due to buffaloes less harassed by mosquitoes than cattle, variation in number of the investigated cases, stress factors to which the animal exposed, sanitary conditions and also immune status of animals which is lower in Frisian breeds than native breeds and buffaloes, but (Walker and Klement, 2015) showed that clinical BEF occurred in cattle and water buffaloes as the same.

Regarding to sex, our study revealed that rate of infection in female animals $(17.31 \%)$ was higher than male animals $(8.33 \%)$, this result was agreement with that reported by (Momtaz et al., 2012; AlSultany and Hassan, 2013 and Akakpo, 2015) and this may be attributed to the higher number of female animals than male ones and inclination of carrier insects to sting females more than males.

Animal age plays a great role in animal susceptibility to BEFV infection as it has been observed that animals aged group $>2$ 4 years $(13.45 \%)$ was more susceptible to infection than animals aged group 6 months-2 years (12.5\%). Our result similar to that previously obtained by (Momtaz et al., 2012; Al- Sultany and Hassan, 2013 and Akakpo, 2015) who concluded that may be due to the frequency of stinging by insects. Contrariwise, (Zaher and Ahmed, 2011) found that young cattle and buffaloes were more susceptible to infection with BEFV than older ages and this may be attributed to lack of immunity in young ages. (Mirazaie et al. 2017) reported that all age groups of cattle were susceptible to BEF, but it has been usually showed more frequently in calves less than 2 years old compared to the other age groups which may be due to delayed methods for diagnosis and treatment.

Dealing with the seasonal variation and BEF infection among infected animals, the present study showed that there was a relationship between the rate of $\mathrm{BEFV}$ infection and the seasonal changes and there was higher rate of infection in hot months $(19.23 \%)$ than non- hot months $(6.41 \%)$, this might be attributed to wide spread of flying insect vectors (mosquito species) that are responsible for transmission of the disease mainly during summer season, although due to lack of rains during summer season, the high temperature together with presence of stagnant water, may create a favorable habitat for vector reproduction, this finding was in agreement with (Yeruham et al., 2010; Al-Sultany and Hassan, 2013; Kasem et al., 2014; Mirazaie et al., 2017 and Zaghawa et al., 2017), but our result was disagreement with that recorded by (Hayama et al., 2016) who mentioned that maintenance of BEFV would be possible in winter season in addition to summer.

\section{CONCLUSION}

$\mathrm{BEF}$ is one of the most important viral disease which infect cattle and buffalo. This disease can be affected by some risk factors such as age, and seasonal variation, 
breed and sex had no effect upon the occurrence of the disease. Serological test (ELISA) is an important tool for the detection of this infection. Molecular technique (RT-PCR) is an important confirmatory and reliable technique for diagnosis of BEFV infection.

\section{REFERENCE}

Abo-Sakaya, R. and Bazan, N.M.E. (2020): Molecular detection of novel bovine ephemeral fever virus strain and its effect on immune system in cattle, Egypt 2017. Benha Veterinary Medical Journal 38: 1-4.

Al-Behwar, A.M.; El-Neshwy, W.M.; Fakhry, H.M. and El-Emam, H.S. (2018): Molecular Characterization of recent isolates of BEF virus in Egypt. Global Journal of Medical Research 18: 2249-4618.

Alkan, F.; Albayrak, H.; Timurkan, M.O.; Ozan, E. and Coskun, N. (2017): Assessment of the molecular epidemiology of bovine ephemeral fever in Turkey. Veterinarski Arhiv 87 (6): 655-675.

Al-Sultany, H.H.O. and Hassan, I.Q. (2013): Molecular investigation of bovine ephemeral fever in Iraq. Veterinary Sciences and Animals 2(3): 42-50.

Aziz-Boaron, O.; Klausner, Z.; Hasoksuz, M.; Shenkar, J.; Gafni, O.; Gelman, B.; David, D. and Klement, E. (2012): Circulation of bovine ephemeral fever in the Middle EastStrong evidence for transmission by winds and animal transport. Veterinary Microbiology 158: 300307.

Bakhshesh, M. and Abdollahi, D. (2015): Bovine ephemeral fever in Iran, Diagnosis, Isolation and Molecular characterization. Journal ArthropodBorne Diseases 9(2): 195-203.
Degheidy, N.S.; Hassan, H.Y.; El-Sanousi, A.A.; Beshir, E. and El-Sadawy, H.A. (2011): Recent trials for diagnosis of bovine ephemeral fever in Egypt. Animal hygiene and sustainable livestock production. Proceedings of the XVth International Congress of the International Society for Animal Hygiene. 3-7 July, Vienna, Austria. 447-451.

El-Nesr, K.A.; Mahdy, E.A. and ElBegawy, M.B. (2010): Bovine ephemeral fever: Pathological and Immunological Studies. Beni-Suef Veterinary Medical Journal 20(1): 63-68.

Hayama, Y.; Moriguchi, S.; Yanase, T.; Suzuki, M.; Niwa, T.; Ikemiyagi, K.; Nitta, Y.; Yamamoto, T.; Kobayashi, S.; Murai, K. and Tsutsui, T. (2016): Epidemiological analysis of bovine ephemeral fever in 2012-2013 in the subtropical islands of Japan. Veterinary Research 12:47.

Huihui, J.; Peili, H.; Hongbin, H. and Hongmei, W. (2020): Cell apoptosis regulated by interaction between viral gene alpha-3 and host heterogeneous nuclear ribonucleoprotein $\mathrm{K}$ virus replication. Veterinary Microbiology 240 (2020) 108510.

Jiang, H.; Hou, P.; He, H. and Wang, $H$. (2019): Cell apoptosis regulated by interaction between viral gene alpha 3 and host heterogenesis nuclear ribonucleoprotein $\mathrm{K}$ facilities bovine ephemeral fever virus replication. Veterinary Microbiology 240: 108510.

Kasem, S.; Dawod, A.; Khodier, M.; Kotb, A.; Abuelyazeed, M.; Abdel Kareem, S. and Ibrahim, B. (2014): Isolation and characterization of bovine ephemeral fever in Delta provinces, Egypt 2012. Global Veterinarina 13(6): 972- 976. 
Kun, J.; Rongrong, J.; Xiangbin, W.; Yan, Z.; Yiping, D.D.; Gang, L.; Pei, Z. and Shoujun, L. (2020): Genetic characterization of bovine ephemeral fever virus in Southern China, 20132017. Virus genes 56: 390-395.

Lapira, J.E.E.; Balbin, M.M.; Belotindos, L.P.; Viloria, V.V.; Abes, N.S. and Mingala, C.N. (2018): Molecular detection of bovine ephemeral fever virus among large ruminants in the Philippines. Virus Diseases 29(3): 400-404.

Lee, F. (2019): Bovine ephemeral fever in Asia: Recent status and research gaps. Viruses 11: 412.

Li, Z.; Zheng, F.; Gao, S.; Wang, S.; Wang, J.; Liu, Z.; Du, J. and Yin, H. (2015): Large-scale serological survey of bovine ephemeral fever in china. Veterinary Microbiology 176: 155-160.

Mirazaie, K.; Bahonar, A.; Mehrabadi, M.H.F.; Hajilu, G. and Yaghoubi, M. (2017): Determinants of bovine ephemeral fever outbreak during 2013, in Qazvin province, Iran. Asian Pacific Journal of Tropical Disease: 7.

Momtaz, H.; Nejat, S.; Moazeni, M. and Riaha, M. (2012): Molecular epidemiology of bovine ephemeral fever virus in cattle and buffaloes in Iran. Revue de Medecine Veterinaire 163: 8-9, 415-418.

Niwa, T.; Shirafuji, H.; Ikemiyagi, K.; Nitta, Y.; Suzuki, M.; Kato, T. and Yanase, T. (2015): Occurrence of bovine ephemeral fever in Okinawa Prefecture, Japan, in 2012 and development of a reversetranscription polymerase chain reaction assay to detect bovine ephemeral fever virus gene. Journal of Veterinary Medical Science 77 (4): 455-460.

Pasandideh, R.; Seyfi, M.R.; Shapouri, A. and Nassiri, M.T.B. (2019):
Production of monoclonal antibody against prokaryotically expressed G1 protein of bovine ephemeral fever virus. Iranian Journal of Applied Animal Science 9 (1): 51-57.

Radiostits, O.; Gay, C.C.; Hinchcliff, K.W. and Constable, P.D. (2007): Veterinary medicine. A text book of the diseases of cattle, sheep, goat, pig and horse. $10^{\text {th }}$ Edition. Saunders Company, United Status of America.

Rosenberger, G. (1979): Clinical examination of cattle. $2^{\text {nd }}$ Edition. Felgentreff and Goebel ICG, Germany.

Tamam, S.M. and Abdel-Moneim, A.S. (2005): Detection of bovine herpes virus type 1 and bovine ephemeral fever virus antigens in cattle lymph nodes using three immunological assays). Beni-Suef Veterinary Medicine Journal 15 (2): 203-207.

Tonbank, S.; Berber, E.; Deniz, M.; Azkur, A.; Pestil, Z. and Bulut, H. (2012): A large scale outbreak of bovine ephemeral fever in Turkey, 2012. Veterinary Medcine and Science 75(11): 1511-1514.

Walker, P.J. and Klement, E. (2015): Epidemiology and control of bovine ephemeral fever. Veterinary Research 46:127.

Zaghawa, A.A.; Housawi, F.; Al- Naeem, A.; El-Sify, A. and Hegazy, Y.M. (2017): Bovine ephemeral fever epidemics in Kingdom Saudia Arabia, clinical, epidemiological and molecular investigation. Journal of Infection in Developing Countries 11(11): 857-860.

Zaher, K.S. and Ahmed, W.M. (2011): Investigation on Bovine ephemeral fever virus in Egyptian cows and buffaloes with emphasis on isolation and identification of a field strain. Global Veterinarin 6(5): 447-452.

Zheng, F. and Qui, C. (2012):Phylogenetic relationships of glycoprotein gene of 
bovine ephemeral fever virus isolated from mainland China, Taiwan, Japan, Turkey, Israel and Australia. Virology Journal 9:268

Zheng, F.; Lin, G.; Qiu, C.; Zhou, J.;
Serological detection of bovine ephemeral fever virus using an indirect ELISA based on antigenic site G1 expressed in Pichiapastoris. Veterinary Journal 185(2): 211-5.

Cao, X. and Gong, X. (2010):

\section{دراسة وبائية لعدوي فيروس حمي الأبقار سريعة الزوال في الماثية و الجاموس في مصر

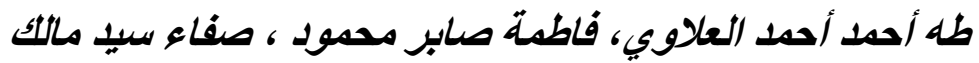

E-mail: safaamalek80@aun.edu.eg Assiut University web-site: www.aun.edu.eg

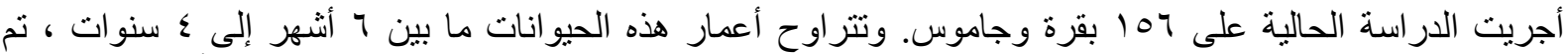

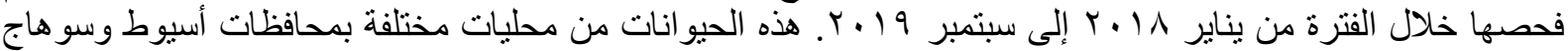

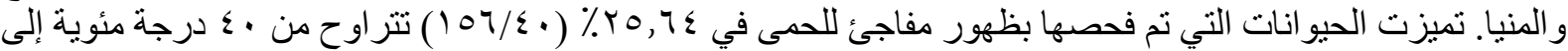

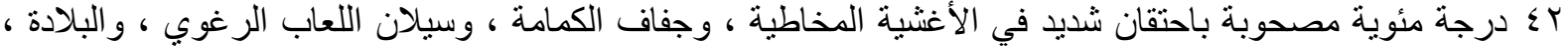

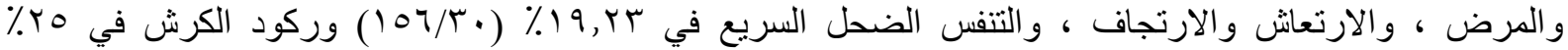

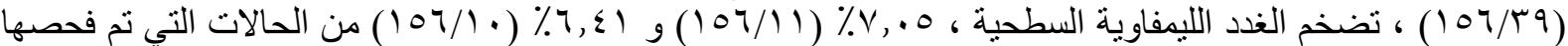

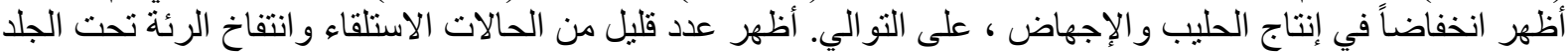

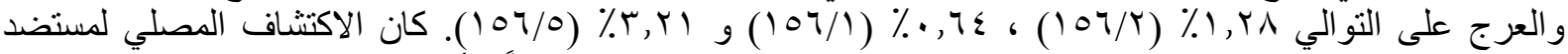

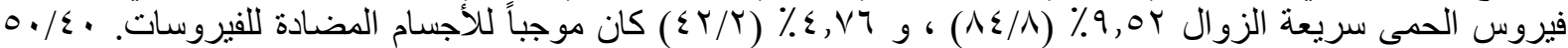

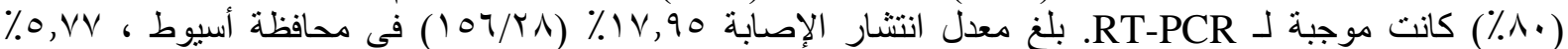

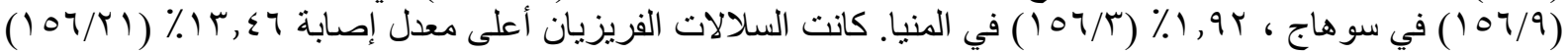

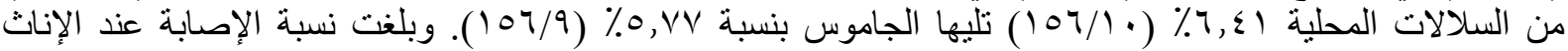

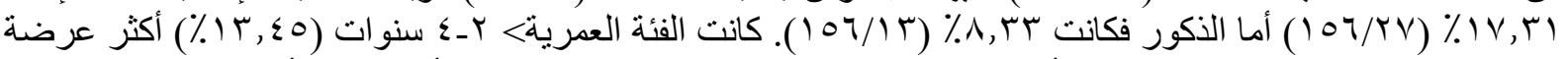

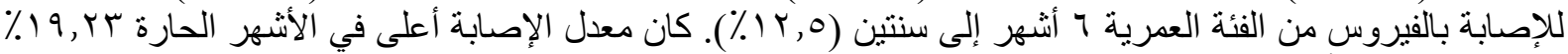

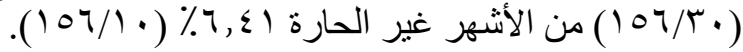

